Covered in: Web of Sciences (WOS); EBSCO; ERIH+; Google Scholar; Index Copernicus; Ideas RePeC; Econpapers; Socionet; CEEOL; Ulrich ProQuest; Cabell, Journalseek; Scipio; Philpapers; SHERPA/RoMEO repositories; KVK; WorldCat; CrossRef; CrossCheck

\section{Fear of Death as the Foundation of Modern Political Philosophy and Its Overcoming by Transhumanism}

\author{
Matías, QUER ${ }^{1}$ \\ ${ }^{1}$ Universidad de los Andes, Chile, \\ mquer@uandes.cl
}

Abstract: Fear, which has always been one of the most powerful of human passions, has grown in importance during modernity. First with Machiavelli and later especially with Hobbes, fear has become one of the foundational ideas of modern political philosophy. If fear, especially fear of death, does indeed occupy a central place in the foundation of modern politics, then it is necessary to study carefully the implications and consequences of the transhumanist attempt to overcome death. Among the main aspirations of transhumanism is the search for almost infinite longevity and, eventually, the total abolition of aging. Therefore, it is necessary to understand the specific role that fear of death has played in modern political philosophy to understand the possible effects that an eventual overcoming of death would have, albeit partial, as wanted by transhumanists. While the possibility of achieving immortality seems unlikely, this doesn't mean that we shouldn't study what's behind this transhumanist aspiration. In this way, transhumanism seems the final consequence of modern development, since it's in continuity with the modern attempt to respond to the fear of death, but it does so by trying an ultimate solution to it through the elimination of death, at least by sickness and old age. In this paper, we will review the role of fear of death in the founding of modern political philosophy by Machiavelli and Hobbes, and then we will analyse the transhumanist attempt to overcome death as a consequence of this fear and its possible political effects.

Keywords: fear; death; transhumanism; modern political philosophy; Hobbes; Machiavelli.

How to cite: Quer, M. (2020). Fear of Death as the Foundation of Modern Political Philosophy and Its Overcoming by Transhumanism. Postmodern Openings, 11(4), 323-333. doi:10.18662/po/11.4/238 


\section{Introduction}

Transhumanism is a recent philosophical phenomenon that consists of the attempt to overcome the natural condition of the human being through technology. The result of the transhumanist project would be a new condition, beyond the human one. For example, for the famous book author Yuval Noah Harari, this new condition would be that of the Homo Deus, instead of Homo sapiens (Harari, 2016). For the same reason, transhumanism can be considered as a form of post humanism, in which the human condition would become obsolete (More, 1990, pp. 6-7). Although the transhumanist movement has different faces and pursues different objectives, one of the most classic and common is the search for a longer and even eternal life, through the overcoming of aging, disease and, finally, death (Diéguez, 2017, p. 22).

To understand transhumanism, it is necessary to go back in history. Of course, ancient philosophy, especially Aristotle, could illuminate many of the problems present in the transhumanist discussion. However, today I want to refer to another moment in our Western history: the beginning of modernity. Although the change from the ancient-medieval world to the modern world cannot be identified with a single moment or specific event, it is possible to determine the influence of some authors as founders of modern thought. If some authors point to Descartes or Bacon, I want to refer rather to the beginning of modern political philosophy. It seems to me that it is possible to identify in Machiavelli and Hobbes the two main authors in charge of making the change from medieval to modern political thought (Strauss, 1987, pp. 296-297, 396-397).

In Machiavelli's case, I believe that he is at the hinge between the two worlds, with one foot on each side or without properly belonging to either of them. Machiavelli, therefore, would be a suitably Renaissance political philosopher, but the author of a series of insights that would later shape modern politics. Precisely Hobbes, during the following century, will be in charge of structuring and developing the foundations of modern political philosophy (Manent, 1990, pp. 55, 64-66, 94). Both authors have some elements in common, such as some important anthropological premises. Today I want to refer specifically to an idea that the Florentine and the British share, this is that fear is a fundamental passion in the life of the human being and is the foundation of its political organization. 
Fear of Death as the Foundation of Modern Political Philosophy ... Matías, QUER

To understand the importance of fear and the novelty that Machiavelli and Hobbes bring on this point with respect to the classics, it is necessary to refer to the turn that modern philosophy makes with respect to teleology. Therefore, before reviewing the role of fear in Machiavelli and Hobbes, it will be necessary to refer briefly to what Robert Spaemann called the teleological inversion of modernity (Spaemann, 1991, p. 278). Once we have understood what this teleological inversion consists of, we can clearly understand the role of the fear of death in the foundation of modern political philosophy. Only after reviewing these two elements, it will be possible to understand how transhumanism is inscribed in continuity with the logic of modernity and seeks to overcome or solve it in a definitive way. It will then be time to review the main transhumanist attempts to overcome aging, illness and death. Finally, we will outline some possible logical consequences if the transhumanist project is partially or totally successful.

\section{The twist of modernity: the teleological inversion}

The French philosopher Olivier Rey, in his book on transhumanism, refers to a concept coined by Robert Spaemann that is fundamental in understanding the primacy of survival that we observe on modernity (Clavell, 2014; Keymer, 2007; Rey, 2018, p. 114; Spaemann, 2014, p. 164). This priority of survival occurs at different levels: the individual -as in Hobbes-, the species -as in Darwinism- and genes -as in Dawkins-. All of them have in common an explanation of human life or existence in terms of survival, self-preservation or self-conservation. In this sense, Olivier Rey lucidly explains that the ancients understood self-preservation as a condition of possibility to be able to develop a life whose ultimate goal was happiness, virtue or the good life.

The moderns, on the other hand, seem to have inverted this logic, in what Spaemann calls the teleological inversion. In short, this teleological inversion identified by the German philosopher consists in the fact that "selfpreservation, instead of being at the service of what deserves to be preserved, becomes the ultimate end, to which everything else is subordinate" (Rey, 2018, p. 114; Spaemann, 1991, p. 277). Preservation of life then becomes the telos, the very end, of all forms of life. This twist appears very clearly in the background of Hobbes's state of nature and social contract. However, self-preservation of life is not limited to individuals or human beings. Once the theory of the evolution of species makes its appearance, Darwinisim applies the same principle of teleological inversion to 
the species as a whole. In other words, every living organism exists simply to try to ensure the survival of its species. Finally, with the developments of genetics, we reached a final step: it would be the genes that would be trying to survive. Life would then ultimately be the attempt of the famous Dawkins selfish genes to achieve survival (Dawkins, 2016, p. 114).

Although there are multiple reasons and arguments to criticize this teleological inversion -especially the way in which it has been applied to individuals, species and genes- for now we will settle for showing it. Thus, if we believe that Spaemann's thesis on teleological inversion is acceptable, it will be time to specifically observe its manifestations at the beginning of modern political philosophy.

\section{The beginning of modern political philosophy: fear in Machiavelli and Hobbes}

As we have said, the beginning of modern political philosophy is usually set between Machiavelli and Hobbes. Although there is greater consensus in considering the British as a modern than in doing so with the Florentine, the truth is that Machiavelli already presents some important breaks with the philosophical tradition that precedes him. In fact, the author of The Prince himself is explicit in the distance that exists between him and his predecessors (Machiavelli, 2018a, P XV, p. 859). Beyond locating the beginning of political modernity in Hobbes or Machiavelli, it is possible to establish some common ground between them. For example, both seem to have a political anthropology that views human beings as selfish and dangerous to each other. In this sense, one of the central concepts for both authors will be fear and, especially in Hobbes, fear of death.

Corey Robin, in his book titled Fear, has demonstrated the importance of this passion as a concept in the history of political ideas (Robin, 2004, pp. 27-30; Aron, 1968, pp. 20-21). In his work, Robin chooses four main authors to show the centrality of fear in political philosophy: Hobbes, Montesquieu, Tocqueville, and Hannah Arendt. It is not by chance, therefore, that fear is a central element only in modernity. Machiavelli, although he is not one of the four central characters, is mentioned on several occasions (Robin, 2004, pp. 28, 31, 39, 90, 136). Furthermore, we know that the Florentine exerts a great influence on modern political philosophers, such as Montesquieu, for example. In what follows, we will briefly show the central role of fear in the political philosophy of Machiavelli and Hobbes. 
The work of Niccolò Machiavelli is one of the most complex to synthesize and harmonize, since it doesn't have a systematic character and has multiple styles and objects. However, there is no doubt that one of the central ideas of his political philosophy is constituted by his famous theory of humors (Lefort, 2010, p. 251). In short, this theory of Machiavelli sustains that every city is constituted by two different humors and that they are opposed: one of the nobles and another of the people (Machiavelli, 2018a, P IX, p. 837). This configuration supposes, as Claude Lefort points out, a radical tearing of society into two parts (Lefort, 2010, p. 212). Each Machiavellian humor is defined as a wish, and one is directly opposed to the other. The humor of the nobles is usually referred to as the desire to dominate, while the people simply wish they were not dominated (Machiavelli, 2018a, P IX, p. 837).

However, a careful look at the Discourses on Livy shows us that Machiavelli also presents the humor of the people as those who wish to acquire what they don't have, while the nobles would simply wish to keep what is already acquired. From this perspective, it would be the people who would have a more active or offensive humor, while the great ones would be in a more defensive position (Machiavelli, 2018b, D I 5, p. 325). This tension between the two ways of understanding each humor can be understood from a passion that seems to explain them: this is, fear. It is possible, therefore, to perceive that the experience of fear is at the base of the theory of humors and of Machiavellian political philosophy. This is what Leo Strauss called "the primacy of terror" in Machiavelli (Strauss, 1964, pp. 199200).

This fear, while it can take different forms, such as fear of punishment, revenge, or the unknown, is ultimately a fear of death (Machiavelli, 2018b, D I 7, p. 332). Therefore, although Machiavelli does not develop as explicitly as Hobbes the centrality of death in the experience of fear, it is unquestionably at the bottom of his entire description of the fear of both nobles and the people. For the Florentine, fear produces a natural desire for security that is present in all persons, and it would be this desire that would provoke the desires described in the humors. People, ultimately, would find themselves in a condition of vulnerability and insecurity that cannot be eliminated. The best example of this situation is found in the chapter dedicated to political conspiracies (Machiavelli, 2018b, D III 6, pp. 581-582). Here, Machiavelli anticipates the logic of the Hobbesian state of 
nature. In sum, the fear of death and the search for security play a fundamental role in Machiavelli's work and explain his theory of humors.

Hobbes, a century after Machiavelli, will make a more extensive and explicit development of the fear of death and the desire for security as the foundation of political life (Manent, 1990, pp. 66-67). In the case of the British, the importance of the fear of death doesn't seem a subject of discussion, as he is quite explicit about it (Hobbes, 2016, pp. 145-146). We know that, for example, the situation in which each person finds himself in the state of nature is terrifying and, in addition, of great insecurity, as he says in the Leviathan: "men live without other security, than $[\ldots]$ their own strength" (Hobbes, 1996, p. 89). It will thus be the fear of death, especially brutal death, which will move each person to unite with the others and accept the social contract: "the passions that encline men to Peace, are Fear of Death; Desire of such things as are necessary to commodious living; and a Hope by their Industry to obtain them" (Hobbes, 1996, p. 90).

At the same time, the social contract will give rise to the modern State as the Leviathan and, therefore, the situation within the social contract will also be one of certain fear, since the Leviathan refers precisely to a beast that inspires fear. Obedience to the State will be subject, in this way, to fear caused by the possibility of punishment. In other words, the State will provoke a fear that will force obedience, but the difference will be that the possible punishments by the Leviathan will depend on a series of rules and will be, for the same reason, predictable.

In the state of nature, on the other hand, the fear of brutal death is complemented by the insecurity caused by not knowing by whom, when and how I may be attacked. Hobbes is explicit in stating that, "there is no way for any man to secure himself" (Hobbes, 1996, p. 87). That is, as in Machiavelli, every man seeks above all to ensure his own existence. He then states that men must conquer and dominate others until they see no force great enough to threaten them, this being a requirement for their own conservation: "this is not more so his own conservation requireth" (Hobbes, 1996, p. 88).

Of course, we could dig further into the importance that selfpreservation has within the Hobbesian system of the social contract. However, before reviewing transhumanism, I would like to underline the similarity that exists between what Machiavelli and especially Hobbes put 
forward, with the teleological inversion described by Spaemann regarding modernity. As we said, teleological inversion results in the end of man being his mere self-preservation or self-preservation (Spaemann, 1963, pp. 50-64). Instead of aiming at a robust ultimate goal such as happiness, the good life, virtue or -in the Christian vision- the holiness and beatific vision of God, it only aims to maintain life (Spaemann, 2014, pp. 164-165). If we take this turn to the field of political philosophy, notions such as the common good, civic friendship or the virtuous life of the citizen cease to be central (as they were for the classics) and, instead, the self-preservation of life guides all political action (now dominated by the fear of being dominated and dying). This would be the change operated between the political philosophy of Plato, Aristotle, Cicero or Saint Augustine and that of Machiavelli and Hobbes.

\section{Transhumanism and immortality}

How does this self-preservation of life fit into the transhumanist movement? As it turns out that one of the main purposes of transhumanism is precisely the maximum extension of human life that science can achieve. In short, transhumanists seek to defeat disease, aging, and death: they desire immanent eternal life. This search is what they have called "the death of death" (Alexandre, 2011). Olivier Rey doesn't hesitate to link this transhumanist obsession with the absence of meaning in modern life (Rey, 2018, pp. 34-35).

In this sense, some of the most famous transhumanist and biotechnological projects, authors and associations in the world would be working and promoting the end of death and disease. For example, the Transhumanist Declaration of Humanity Plus (Humanity +), the most important transhumanist association that includes some of the world's most recognized transhumanists - such as Nick Bostrom, Max More (1990) and Natasha Vita-More (2020) - begins as follows: "Humanity stands to be profoundly affected by science and technology in the future. We envision the possibility of broadening human potential by overcoming aging, cognitive shortcomings, involuntary suffering, and our confinement to planet Earth" (Transhumanist Declaration, 1992). In other words, the first change that transhumanism pursues is precisely the overcoming of aging. A similar promise is made in the Transhumanist Manifesto (Vita-More, 2020). In the same way, gerontologist Aubrey de Grey has devoted himself to promoting the possibility of avoiding aging and achieving a life that seems 
immortal with books like Ending Aging and TEDTalks. Its main proposal consists of the so-called SENS (Strategies for Engineered Negligible Senescence), a series of therapies to prevent cellular aging and the diseases that are associated with it (de Grey, 2007, pp. 335-340).

But transhumanism is not only manifested in words and dreams, it also moves tons of millions of dollars invested in biotechnology companies. Perhaps the best examples of this are Calico -California Life Company, a subsidiary of Alphabet, owner of Google- and the Chan Zuckerberg Initiative owned by the owner of Facebook and his wife. While these companies are a little less explicit and daring than Humanity + or Aubrey de Gray, their aims speak volumes. Calico states, "Our mission is said simply, yet it is quite ambitious. We want to better understand the biology that controls aging and lifespan... and we want to use the knowledge we gain to discover and develop interventions that enable people to live longer and healthier lives" (California Life Company, n.d.). While the Chan Zuckerberg Initiative proposes Science among its work focuses, in the following sense: "Supporting the science and technology to make it possible to cure, prevent, or manage all diseases by the end of this century" (Chan Zuckerberg Initiative, n.d.).

It is clear then that, within the broad transhumanist movement and biotechnological advance, the idea of achieving a life without aging or disease, avoiding death -or limiting it to accidents and homicides- is present in a transversal way. In this sense, it is possible to inscribe this desire in perfect continuity with the modern teleological inversion described by Spaemann (Spaemann \& Low, 1981). If our main goal is the self-preservation of life, then transhumanism offers the final and definitive solution to the problem. If the fear of death founds modern political philosophy, the biotechnologygenetic revolution would definitively free us from this problem. The political solution would be replaced by a supposedly peaceful and innocuous technological solution.

\section{Conclusions and perspectives}

However, the reality is more complex than what transhumanists and large biotech companies think, wish or say. For example, there are serious scientific evidence of the limit of human lifespan (Dong et al., 2016, pp. 257265; Oeppen \& Vaupel, 2002; Vijg \& Campisi, 2008). As a conclusion, therefore, I would like to offer some of the problems that we can glimpse 
Fear of Death as the Foundation of Modern Political Philosophy ... Matías, QUER

regarding the eventual overcoming of aging, disease and death desired by transhumanism.

First, there is an anthropological premise that some transhumanist currents tend to ignore. It is about the corporal or material dimension of each human person. Some transhumanists dream of the possibility of uploading their consciousness or minds to a cloud to avoid death, because if necessary it could be downloaded to another body or container. In this way, immortality would be guaranteed. However, there is no evidence that allows us to consider realistic the possibility of loading our mind or consciousness as if it were a file. And, even if that were possible, the cloud is still dependent on a physical support, so death would not be avoided.

In any case, I think the biggest problems could come from two other aspects. The first is the loss of meaning in life and the absolute distortion of human relationships. A life that lasted 1000 years, for example, would generate a feeling of absence of temporal movement, of vitality, it would seem more like the existence of an ancient tree or, worse still, of a rock. Life would lose the natural arc that it has between childhood and old age. Let us remember that the teleological inversion is not equivalent to the absence of telos (end), but to a turn with respect to the end of human life. In other words, the teleological inversion has generated that our goal is self-preservation, but it would be even worse if that single goal were achieved and we no longer had any life horizon. Likewise, personal relationships such as marriage, parenting, and the (usual) experience of meeting grandchildren and -in rare ocassions- the fourth or fifth generation, would be completely blurred. What sense would the relationship of an 800-year-old father have with a 770-yearold son, when he at the same time would have more than 10 generations of relatives down? On the other hand, if death could only come from accidents or murders, what would our social and political coexistence be like? It is possible to imagine a life of extreme anxiety, fear and distrust towards the other, among other phenomena.

Finally, and this is always an important question, what would happen to the radical inequality in our society? What would prevent enhanced (transhuman) beings from submitting us through fear? The division of society would be even more extreme than we have ever imagined. Some will argue that everyone could access these improvements, but we know that, in reality a technological or scientific advance is never universal and free. Even 
more, there is nothing to suggest that everyone would be willing to receive these improvements for themselves or their children.

We have been able to establish the centrality of the fear of death in the foundation of modern political philosophy and its link with teleological inversion. In the same way, we have reviewed the irruption of the transhumanist movement in continuity with the desire for self-preservation proper to that teleological inversion. Finally, we have presented some of the anthropological, social and political problems that the partial or total success of the transhumanist project would suppose. In this way, we have been able to locate transhumanism and show one of the reasons why it can be considered a form of post humanism and postmodernism.

\section{References:}

Alexandre, L. (2011). La mort de la mort. J. C. Lattès.

Aron, R. (1968). Main currents in sociological thought I: Montesquieu, Comte, Marx, Tocqueville, the Sociologist of the Revolution of 1848 (R. Howard \& H. Weaver, Tans.). Doubleday.

California Life Company. (n.d.). Mission. https://www.calicolabs.com

Chan Zuckerberg Iniciative. (n.d.). What we work on: Science. https:// chanzuckerberg.com

Clavell, L. (2014). Redescubrir la finalidad natural. Robert Spaemann y Tomás de Aquino [Rediscover the natural purpose. Robert Spaemann and Thomas Aquinas]. Sapientia, LXX, 5-20.

Dawkins, R. (2016). The selfish gene (40 th Anniversary Edition). Oxford University Press.

De Grey, A. (2007). Ending aging. St. Martin's Publishing Group.

Diéguez, A. (2017). Transhumanismo: La búsqueda tecnológica del mejoramiento bumano [Transhumanism: The technological quest for human enhancement]. Herder.

Dong, X., Milholland, B., \& Vijg, J. (2016). Evidence for a limit to human lifespan. Nature, 538(7624), 257-265. https://doi.org/10.1038/nature19793

Harari, Y. N. (2016). Homo Deus. Random House.

Hobbes, T. (1996). Leviathan. Cambridge University Press.

Hobbes, T. (2016). De Cive. Alianza Editorial.

Humanity Plus. (1992). Tranhumanist Declaration. https://humanityplus.org/ philosophy/transhumanist-declaration/ 
Fear of Death as the Foundation of Modern Political Philosophy ... Matías, QUER

Keymer, M. P. (2007). Bien y naturaleza: Algunas coincidencias entre Robert Spaemann y Charles Taylor [Good and nature: Some coincidences between Robert Spaemann and Charles Taylor]. Pensamiento y Cultura, 10, 39-49.

Lefort, C. (2010). Maquiavelo. Lecturas de lo político [Machiavelli. Political readings] (P. Lomba, Trans.). Editorial Trotta.

Machiavelli, N. (2018a). Il Principe [The prince]. In M. Martelli (Ed.), Tutte le Opere [Complete works] (2nd ed.). Bompiani.

Machiavelli, N. (2018b). Discorsi sopra la prima deca di Tito Livio [Speeches on the first decade of Tito Livio]. In M. Martelli (Ed.), Tutte le Opere [Complete works] (2nd ed.). Bompiani.

Manent, P. (1990). Historia del pensamiento liberal [History of liberal thought]. Emecé Editores.

More, M. (1990). Transhumanism: Toward a futuristic philosophy. Extropy, 6, 6-11. https://www.scribd.com/doc/257580713/Transhumanism-Toward-aFuturist-Philosophy

Oeppen, J., \& Vaupel, J. (2002). Demography. Broken limits to life expectancy. Science, 296(5570), 1029-1031. https://doi.org/10.1126/science.1069675

Rey, O. (2018). Leurre et malheur du transhumanisme [Lure and misfortune of transhumanism]. Desclée De Brouwer.

Robin, C. (2004). Fear. Oxford University Press.

Spaemann, R. (1963). Bürgerliche ethik und nichtteleologische ontologie en Reflexion und spontaneität: Studien über Fénelon [Civil ethics and non-teleological ontology. Reflection and spontaneity: Studies on Fénelon]. Kolhammer.

Spaemann, R. (1991). Teleología natural y acción [Natural teleology and action]. Anuario Filosófico, 24, 273-288.

Spaemann, R. (2014). Sobre Dios y el mundo: Una autobiografía dialogada [On God and the World: A Dialogue Autobiography]. Palabra.

Spaemann, R., \& Löw, R. (1981). Die Frage Wozu? Geschichte und Wiederentdeckung des teleologischen Denkens [The question why? History and rediscovery of teleological thought]. Piper Verlag.

Strauss, L. (1964). Meditación sobre Maquiavelo [Meditation on Machiavelli] (C. Gutiérrez de Gambra, Trans.). Instituto de Estudios Políticos.

Strauss, L., \& Cropsey, J. (Eds.). (1987). History of political philosophy (3rd ed.). The University of Chicago Press.

Vijg, J., \& Campisi, J. (2008). Puzzles, promises and a cure for ageing. Nature, 454(7208), 1065-1071. https://doi.org/10.1038/nature07216

Vita-More, N. (2020). Transhumanist Manifesto (4th ed.). https://humanityplus.org/ transhumanism/ 